\title{
APPLICATION OF AIRBORNE GEOPHYSICAL DATA TO MINERAL EXPLORATION IN THE UNEVEN EXPOSED TERRAINS OF THE RIO DAS VELHAS GREENSTONE BELT
}

\author{
ADALENE MOREIRA SILVA ${ }^{1,2}$, AUGUSTO CÉSAR B. PIRES ${ }^{2}$, ANNE MCCAFFERTY ${ }^{3}$, \\ ROBERTO ALEXANDRE VITÓRIA DE MORAES ${ }^{2}$ \& HENGREN XIA ${ }^{4}$
}

\begin{abstract}
Resumo APLICAÇÃO DE DADOS AEROGEOFÍSICOS À EXPLORAÇÃO MINERAL EM TERRENOS IRREGULARMENTE EXPOSTOS DO GREENSTONE BELT RIO DAS VELHAS A abordagem geofísica utilizada neste trabalho consiste no processamento e realce de dados geofísicos, os quais puderam ser interpretados com ênfase no contexto geológico. O raciocínio usado é que, em exploração, não se deve observar apenas as anomalias geofísicas, mas também as respostas relacionadas à mineralização, à litologia e às estruturas que podem ter importância econômica.A interpretação de dados magnéticos de alta resolução forneceu tanto uma visão geral da arquitetura regional, bem como uma melhor compreensão dos controles estruturais dos depósitos auríferos hospedados no Greenstone Belt Rio das Velhas. Os quatro mapas radiométricos (contagem total, potássio, urânio e tório) foram realçados individualmente pela manipulação de seus histogramas e, posteriormente, apresentados em falsa cor, na forma de imagens ternárias (R:G:B= $\mathrm{K}: \mathrm{U}: \mathrm{Th}$ ). Unidades litológicas individuais podem ser traçadas, uma vez que possuem resposta radiométrica distinta. Uma transformação logarítmica foi aplicada aos dados de condutividade, no intuito de distribuir melhor o intervalo de valores. Isso também permitiu uma melhor interpretação visual dos dados e de sua relação com as fontes geológicas. As rochas hospedeiras mais importantes, ou domínios mineralizados, mostram alta resposta de condutividade. Existe uma correlação forte entre estes domínios e as formações mapeadas como Morro Vermelho, Quebra Osso e Córrego Ouro Fino. Estes domínios abrigam as mineralizações auríferas conhecidas, ilustrando a utilidade do procedimento adotado na melhora do mapeamento geológico e na compreensão da mineralização.
\end{abstract}

Palavras-chaves: Projeto Rio das Velhas, Magnetometria, gamaespectrometria, eletromagnetometria no domínio do tempo, mineralização aurífera.

\begin{abstract}
The highly prospective nature of the Rio das Velhas Greenstone Belt is known since the end of the last century. Archean greenstone-hosted gold deposits represent a distinctive group with many common characteristics. The geophysics approach employed concentrated on processing and enhancing the geophysical data to accurate positioning of geological boundaries. The rationale was that in exploration, we should not be looking for geophysical anomalies, but the responses related to mineralization, lithology, and structure that may have economic importance. Aeromagnetics identifies magnetic greenstone units, important structures related to mineralization and allowed a better understanding of sctrutural geophysical pattern. The radiometric data was an excellent tool for mapping and trace individual lithological units in the in areas of outcrop. The most important host rocks or mineralized domains show high conductivity response. There is a strong correlation of these domains with the mapped Morro Vermelho, Quebra Osso and Ouro Fino Formations. Such domains host the known gold mineralization, illustrating the utility of the EM data to improve the geologic map.
\end{abstract}

Keywords: aeromagnetic, gamma ray, frequency domain EM data, gold mineralization

\begin{abstract}
INTRODUCTION
The interpretation of airborne geophysical data in Greenstone Belt areas in Brazil requires the use of all relevant techniques for better define geological boundaries and important targets to mineral exploration. High-resolution airborne geophysical data shows as a usefulness high quality approach that allows extracting geological information from data (Silva 1999). The rationale is that geophysical pattern mapping is relatively inexpensive when compared to drilling and should also be routinely applied to uneven exposed terrains (Gunn et al. 1997, Meyers
\end{abstract}

et al. 2001).

Poor outcrop and deep weathering characterize the Rio das Velhas Greenstone Belt in the southeastern from Brazil. However, the airborne geophysical data maps greenstone units, such as mafic, ultramafic and banded iron formations, faults and shear zones (Silva 1999). This paper summarizes the use of high-resolution airborne surveying for mineral exploration studies, presenting the enhancements and interpretation of the magnetic, radiometric and frequency domain electromagnetic data of the Rio das Velhas

1 - Departamento de Geologia e Recursos Naturais, Instituto de Geociências, Unicamp, Campinas, SP, Brazil, 13083-970 (adalene@ige.unicamp.br); 2 - Laboratório de Geofísica Aplicada, Instituto de Geociências, Universidade de Brasília, Brasília, DF, Brazil, $70910-900$ (acbpires@unb.br \& rmoraes@unb.br);

3 - United States Geological Survey, Box 25046, Mail Stop 964, Denver Federal Center, Denver, CO, USA, 80225 (anne@usgs.gov)

4 - Department of Geophysics, Colorado School of Mines, Golden, CO, USA (hxia@mines.edu) 
Greenstone Belt.

GEOLOGIC OVERVIEW The QF is situated in the southern portion of the São Francisco Craton and is composed of Archean granite-gneissic terrains (GGTs); Archean Greenstone Belt (Rio das Velhas Supergroup); Paleoproterozoic (Minas Supergroup and Itacolomi Group) and Paleoproterozoic-Mesoproterozoic (Espinhaço Supergroup) supracrustal units (Fig. 1).

The supracrustal units, namely Minas and Rio das Velhas Supergroups, surround and are surrounded by granite-gneiss domes and each has been named: Bação, Caeté, Bonfim, Belo Horizonte and Santa Rita. These domes consist of poly-deformed gneiss, metatonalites to metagranites, amphibolites, meta-ultramafic rocks, as well as pegmatites formed in amphibolites facies conditions during the Archean and in the Tranzamazonic Eras (Cordani et al. 1980). The contact with adjacent supracrustal units is tectonic.

The Rio das Velhas Supergroup (RVSG - 3.0-2.7 Ga) is divided in two groups. The first, Nova Lima Group (NLG) comprises a lower ultramafic unit, an intermediate felsic-mafic unit and a clastic-mafic-felsic unit (Ladeira 1980). These rocks are overlain by quartzites of Maquiné Group.

THE RIO DAS VELHAS GREENSTONE BELT The Quadrilátero Ferrífero (QF) covers an area of approximately 7190 $\mathrm{km} 2$, of which approximately $1800 \mathrm{~km} 2$ are underlain by the Rio das Velhas Greenstone Belt (Fig. 1). This region is one of the most important gold provinces in the world and has been a major factor in the economic development of Brazil. The Archean greenstone-hosted gold deposits include several styles of mineralization and are divided into the Nova Lima, Caeté, and Santa Bárbara Districts.

Stratigraphy Ladeira (1980) suggested subdividing the Nova Lima Group into three units, from lower to upper: a) metavolcanic unit composed of metaultramafic, metabasalt, metatuffs, and metakomatiites with spinifex structure, intercalated with a banded iron formation of the Algoma type. This unit corresponds to Quebra Osso Group (Schorscher 1978); b)chemical metasedimentary unit composed of intercalated carbonaceous schist, metachert banded iron formation and carbonaceous phyllites. This unit, defined by Ladeira (1980), focused on the gold districts of Nova Lima and Raposos, and was subdivided into two sub-units: The Lapa Seca and the Raposos Formations and c) the clastic metassedimentary unit composed of metaconglomerate, sandstone, and quartz schist.

Oliveira et al. (1983) and Vieira \& Oliveira (1988) proposed the subdivision of the Nova Lima Group, at the type locality into three units: an Upper Unit, a Middle Unit and a Lower Unit. For the Caeté District, Oliveira (1986) proposed the following subdivision from bottom to top: Mafic/Ultramafic Unit, Pelitic Unit, Acid Intermediary Unit, Undivided Sedimentary Unit and Psammitic Unit. Oliveira (1986) considers the molasse unit, the base of the Maquiné Group (Palmital Formation - O'Rourke 1957), as being correlative with upper unit of the Nova Lima Group (Psammitic metasedimentary Unit).

The Maquiné Group (Dorr et al. 1957) is predominately clastic and was divided into two formations: Palmital (Lower) and Casa Forte (Upper) (Dorr 1969). The Palmital Formation (O' Rourke 1957) includes, from bottom to top, a basal polymictic metaconglomerate, schist, quartz schist, phyllite, and metagreywacke. The Casa Forte Formation (Gair 1962) is composed of sericitic, chloritic and schistose quartzite and phyllite. The Palmital - Casa Forte contact is gradational and is marked by conglomerate.

Recently, the Rio das Velhas Supergroup was divided into informal lithostratigraphic units by Zuchetti et al. (1996) based on field observations, petrologic and geochemical studies. Pinto $\&$ Silva (1996) proposed the upgrading of these units to formation status. The units were grouped into the four following tectonic blocks (Pinto 1996): Nova Lima, Caeté, Santa Bárbara, and São Bartolomeu. These blocks represent distinct petrogenetic environments.

Along with these modifications, the formal designation of the Rio das Velhas Supergroup was kept, with the Nova Lima Group (bottom) and Maquiné (top). On the other hand, the Córrego dos Boiadeiros Complex and the Quebra Osso Group were redefined as formations within the Nova Lima Group. The Córrego dos Boiadeiros Complex was separated as an intrusive ultrabasic sill at the bottom of the Nova Lima Group (Pinto 1996, Zuchetti et al. 1996, Pinto \& Silva 1996). According to Pinto \& Silva (1996), three formations (Córrego Ouro Fino, Córrego dos Boiadeiros, and Quebra Osso Formations) belong at the base of the Nova Lima Group and are present in the Caeté, Nova Lima, and Santa Bárbara Blocks (Fig. 2).

The metasedimentary rocks were previously assigned to six formations: Córrego do Sítio (Caeté, Nova Lima and Santa Bárbara Blocks), Mindá (Caeté, Nova Lima and Santa Bárbara Blocks), Catarina Mendes, Córrego da Paina, Fazenda Velha and Pau D’Óleo (São Bartolomeu Block) (Pinto \& Silva 1996, Fig. 2).

Tectonic Evolution The Quadrilátero Ferrífero is marked by a complex multi-phased history, which resulted in the heterogeneous superposition of successive tectonic events (Endo et al. 1996). Granite-gneiss terrains older than $3000 \mathrm{Ma}$ are considerably more complex than younger ones. In addition, younger ones that have yielded 2700 to $2800 \mathrm{Ma}$ ages have a NS foliation with horizontal mineral lineation, which formed coevally with the NS structures of QF, which are well displayed in the Bonfim Complex (Chemale Jr. et al. 1991, 1994).

Gold Mineralization According to Ribeiro-Rodrigues (1998), the QF gold production reached approximately 910ton. The Archean greenstone-hosted deposits are responsible for 53\% of this production and constitute the majority of the inactive and active mines. Banded iron formations are by far the most important hosts of gold mineralization. They can be divided in three types: oxide type (Raposos, Espírito Santo), carbonatesulphide type (Cuiabá, Lamego) and ankerite/ferroan dolomite, quartz and plagioclase type (Lapa Seca - Morro Velho, Bicalho, Juca Vieira).

AIRBORNE ACQUISITION The Rio das Velhas airborne project was surveyed with a Bell-212/PT-HKV helicopter due to rugged terrain and the weight of equipment. The airborne survey was flown at a constant ground clearance. The airborne data were acquired using $250 \mathrm{~m}$ spaced flight lines with orthogonal tie lines flown every $5000 \mathrm{~m}$ at $45 \mathrm{~m}$ above the ground surface (Hildenbrand \& Perez da Gama 1993). The survey design was done in different blocks with different flight- and tie-line direc- 


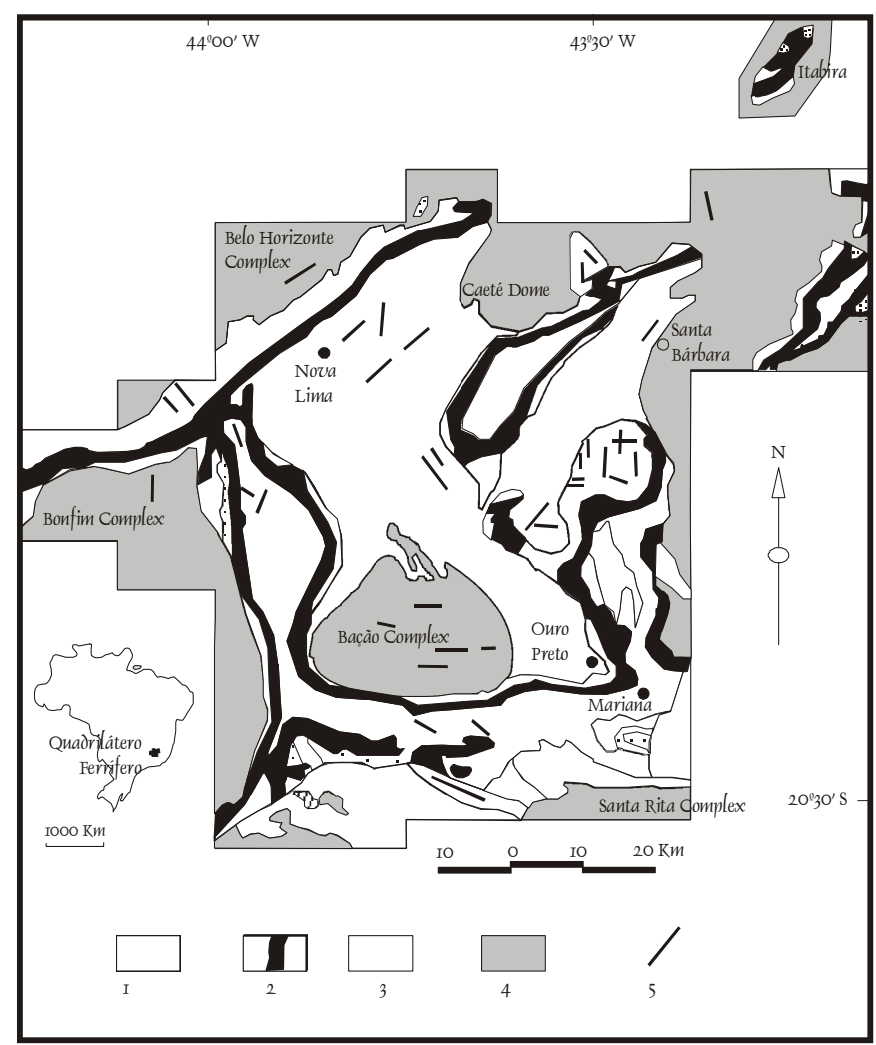

Figure 1- Geological sketch of Quadrilátero Ferrifero (Modified from Dorr 1969). 1-Granite-gneiss terrains, 2-Rio das Velhas Supergroup, 3-Minas Supergroup, 4-Espinhaço Supergroup, 5-Mafic dyke swarms. tions to run perpendicular to the internal structures of Rio das Velhas Greenstone Belt.

The magnetic system used was a AERODAT/IFG magnetometer coupled helium sensor. The output from the magnetometer was sampled at $0.2 \mathrm{~s}$ to a resolution of $0.01 \mathrm{nT}$ with noise envelope of $0.1 \mathrm{nT}$. The sensor was kept at a constant height of $45 \mathrm{~m}$ above the ground. The non-geological effects was accomplished by the use of GEOMETRICS G-803 proton-procession magnetometer, with records of magnetic field of $0.1 \mathrm{~s}$.

The EXPLORANIUM spectrometer, model GR-820 with 256 spectral channels and EXPLORANIUM detector GPX-1024, 1024 cubic inches of $\mathrm{NaI}(\mathrm{Tl})$ (Sodium iodide crystals treated with thallium) were accopled in the helicopter. The instrument was kept at a constant height of $60 \mathrm{~m}$ above the ground. The sample tax was 1 register/second each $25 \mathrm{~m}$.

The helicopter electromagnetic system (HEM) utilized was AERODAT 5 ELECTROMAGNETOMETER coupled three horizontal coplanar bobbins with the frequencies of 500, 4175 and $33000 \mathrm{~Hz}$ and two vertical coaxial bobbins of frequencies de 935 and 4600 separated of $7 \mathrm{~m}$. The sensor, bird type, was kept at a constant height of $30 \mathrm{~m}$ above the ground (Hildenbrand \& Perez da Gama 1993) with sample tax of 5 register/second each $5 \mathrm{~m}$.

PROCESSING OF THE AIRBORNE GEOPHYSICALDATA This section gives an overview of the processing of airborne data in Rio das Velhas project, referring to different methodologies used in this work. The processing of airborne data involved the sequential processes of editing, the application of a gridding routine, removal of the Earth's background magnetic field and microleveling of all data to a common base. Some corrections like removing diurnals were made by the company that acquired

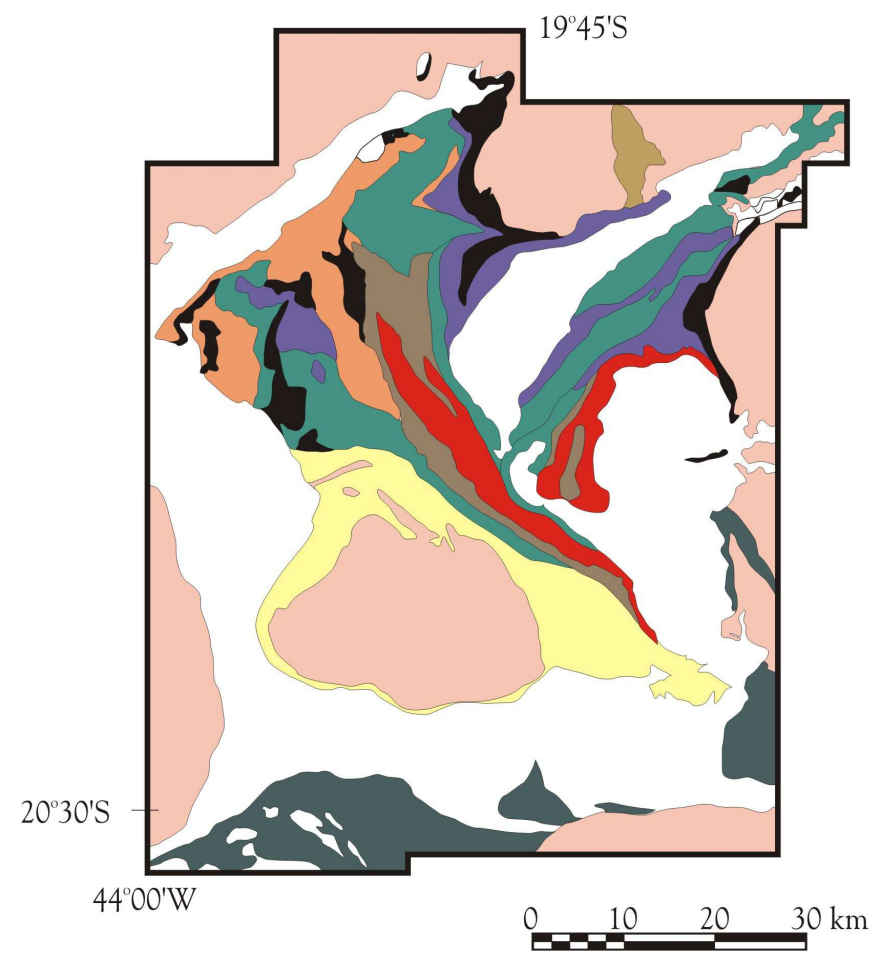

\section{LEGEND}

Espinhaço Supergroup

Minas Supergroup

RIO DAS VELHAS SUPERGROUP

MAQUINÉ GROUP

$\square$ Casa Forte Formation

Palmital Formation

NOVA LIMA GROUP

Metassediments of Mixed Sources

(Greenschist to Amphibolite Facies)

Metassediments of Mixed Sources

(Greenschist Facies)

$\square$ Volcanoclastic Metassediments

Chemical-exhalative Metassediments

Mafic-ultramafic Magmatism

$\square$ Undivided Rio das Velhas Supergroup

Granite-gneiss Terrains

Figure 2 - Simplified geologic map of the Rio das Velhas Greenstone Belt with the new stratigraphic sub-division proposed by Pinto \& Silva (1996). 
the airborne survey data.

The general processing of airborne geophysical data in this work involved six major steps in two phases: pre-processing and processing of airborne data. The pre-processing phase was made in two steps: a) extraction of the raw data from original tapes with $\mathrm{C}^{++}$program and $\mathrm{b}$ ) locating the data in $\mathrm{x}$ and $\mathrm{y}$ with USGS software. The second phase accomplished four steps: a) gridding; b) calculating the definitive geomagnetic reference field (DGRF), removing it from the observed magnetic data, c) microleveling the entire data set to remove any apparent residual errors and d) merging the four different blocks for each different data type.

The geophysical data set from Rio das Velhas project have been co-registered to Universal Transverse Mercator Coordinate System, south hemisphere, and zone 23. These data were obtained and processed in a variety of formats including USGS software, Geosoft, Surfer (Golden Software) and ER Mapper 6.0.

The irregularly spaced data were gridded to a 50-meter interval using a computer program developed by Webring (1981) based on a minimum curvature technique (Briggs 1974). Once a grid was produced it was displayed as an image. Four different types of grids for each data set were processed and these correspond to different blocks of the survey.

The magnetic-anomaly grid [total field intensity minus the Definitive International Geomagnetic Reference Field: (DGRF)] was calculated (Sweeney 1990) for the appropriate time of year and elevation of the original survey.

The grids were leveled each one in accord to different flight line directions with USGS software. The DECORBL program decorrugates a standard grid using a Blackman filter. The input allows an azimuth angle for the corrugation to be entered, and a width interval. After microleveling was accomplished, the corrected grids were merged and posterior enhancements were applied to the entire data set.

METHODS AND RESULTS Airborne geophysical data can be enhanced by a range of linear and non-linear filtering algorithms. A range of imaging routines can be specified to visually enhance the effects of selected geologic sources using mathematical enhancement techniques (Millingan \& Gunn 1997).

The following discussion describes some enhancement techniques and their results. Because it is known that significant concentrations of mineral deposits are correlated with high frequency magnetic responses, high-pass, horizontal gradient and terracing filters were applied to the aeromagnetic data in order to enhance high frequencies and define body edges. The terrace filter has been applied to the electromagnetic data.

The aeromagnetics Although the magnetic method has been widely used in mineral exploration for decades, recent improvements in magnetic data acquisition, processing and presentation have increased the importance of magnetic surveys; particularly the high resolution aeromagnetic surveys (Clark 1997). This great advance to aeromagnetic interpretation has been a change in the survey design that better map short wavelengh, low-amplitude magnetic anomalies (Grauch \& Millegan 1998) and is a time and cost-effective method of mapping the Earth's magnetic field. Magnetic anomalies in the Earth magnetic field are caused by magnetic minerals in the rocks, and maps and images of these anomalies can be interpreted in terms of geology. Analytical techniques applied to the magnetic data provide new interpretative information by enhancing particular trends or wavelengths. Magnetic expressions of structures and lithologic variations within the Rio das Velhas greenstone belt are enhanced.

REDUCTION TO THE POLE TO LOW LATITUDES (RTP) A reduction-to-pole (RTP) filter for low geomagnetic latitudes (Phillips 1997) was applied to the magnetic anomaly data. The approach utilizes an azimuthal filter in the frequency domain to minimize the directional noise caused by the low geomagnetic latitude. The calculation of inclination and declination were made using the central coordinates of the area (longitude: $-43^{\circ} 45^{\prime}$ and latitude: $20^{\circ} 7^{\prime} 30^{\prime \prime}$ ) and point out an inclination of $-29.18^{\circ}$ and declination of $-20.99^{\circ}$ to a total field of $23873.5 \mathrm{nT}$.

The reduced-to-pole magnetic anomaly map (Fig. 3) shows that both low and high frequency characterize the magnetic field in the area. The high frequency positive anomalies map magnetite-rich banded iron formation (BIF) and metavolcanoclastic rocks. The elongate high frequency anomalies in the northeast (A on Fig. 3) are also associated with the strips of Archean banded iron formation that made contact with chemical-exhalative metassediments of the Rio das Velhas Greenstone Belt. North-south structures in the southern portion of the area are featured reduced-to-pole magnetic anomaly map (B on Fig. 3). The circular anomaly (C on Fig. 3) is correlated with the Ouro Fino Syncline (Minas Supergroup) that occurs inside of the Rio das Velhas area. The positive magnetic values result from to the Lake Superior banded iron formation hosted in the syncline.

There are two large Paleoproterozoic structures that can be mapped with the aeromagnetic data: the Bem-te-vi and São Vicente faults (D and E on Fig. 3). The Bem-te-vi fault separates different magnetic domains in the Greenstone Belt. The São Vicente system is one of the most important gold structural controls. It also marks the contact between the Nova Lima and Maquiné Groups.

HIGH-PASS OF RTP Frequencies within a defined range can be removed from magnetic data by simply eliminating the specified frequency range from the spectrum of the data. If the magnetic data set contains a series of high frequency anomalies with shallow sources and the high frequency are of special interest, then in principle it is possible to remove a series of deep anomalies, represented as low frequencies, with high pass process. The success of this technique depends on the difference in frequency content of deeper-source anomalies relative to shallow-source anomalies. Interesting results can be obtained in the cases of a data set with different frequencies, but several distortions can be occurring. The high pass map of reduced-to-pole anomaly data in this research was obtained from the following operation: upward continuation of reduced to pole anomaly data to 150 meters minus the reduced-to-pole anomaly data.

TERRACING The terracing technique (Cordell \& McCafferty 1989) was applied to aeromagnetic data after it was reduced-topole to create a terrace-magnetization map. Comparing the images with the Rio das Velhas geologic map it is possible to see geologic features that can be correlated to the reduction-to-pole and terrace-magnetization maps.

However, the long wavelengths, present in the reduced-to-pole data, often do not permit one to see the shorter wavelength anomalies corresponding to important features related to mineralization. It is often useful to filter the potential field data prior to terracing to enhance features of particular interest. Because of that, the terrace 


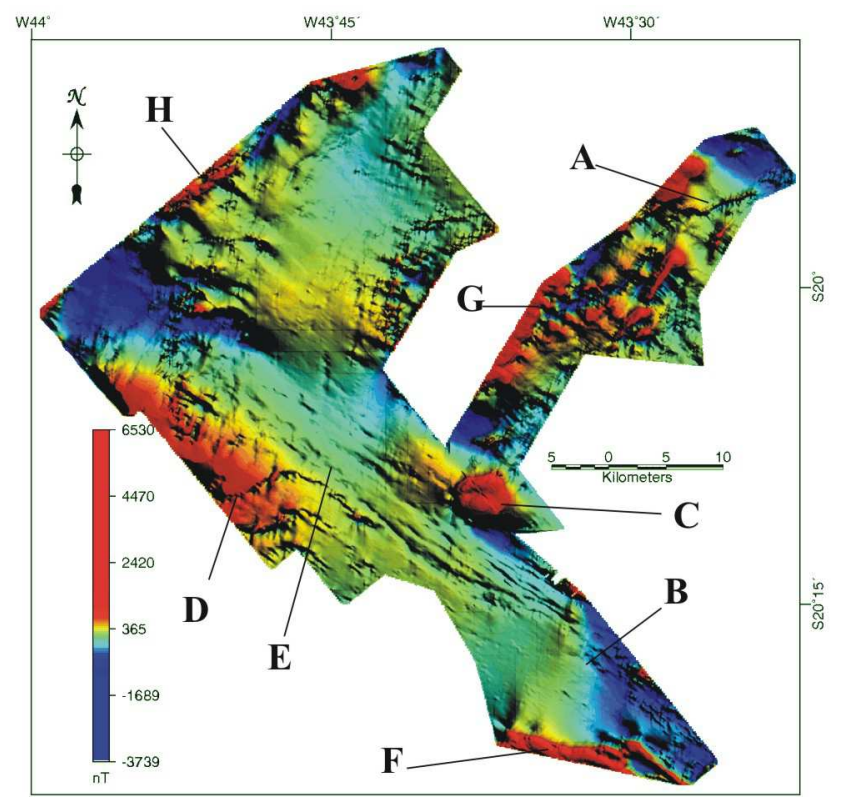

Figure 3-Map showing reduced-to-pole magnetic anomaly data with illumination form northeastern. Histogram equalized, blue low, red high. A- High-frequency anomalies associated with strips of Archean banded iron formation from the Rio das Velhas Supergroup, B-North-South Structure, C-Ouro Fino Syncline, DBem-te-vi Fault, E-São Vicente System, F, G, and H-High frequency associated with the Paleoproterozoic banded iron formation from the Minas Supergroup.

filter was applied to the high-pass. The goal was to point out the form and amplitude of magnetic responses of mineral deposits in Greenstone Belt Rio das Velhas, where the highest concentration of the important mineralized sites is located (Fig. 4).

ANALYTIC SIGNAL AMPLITUDE Nabighian(1972) developed the concept of analytical signal, or energy envelope, of magnetic anomalies. An important characteristic of the analytical signal is that is independent of the direction of the magnetization of the source. The amplitude of the analytical signal is related to amplitude of magnetization.

The 3D analytic signal amplitude (Roest et al. 1992) was calculated from the residual magnetic field. The analytic signal amplitude is independent of the direction of the magnetization of the source, and is related to amplitude of magnetization (Nabighian 1972, Roest \& Pilkington 1993). The most significant concentrations of mineral deposits in this area are correlated with high analytical signal amplitudes (Fig. 5).

The Gamma ray Airborne gamma-ray data are used as an aid to lithological mapping. Many times, there is a good correlation between patterns in the radiometric data and unweathered rocks (Gunn et al. 1997). This information compliments magnetic, electromagnetic and geochemical data normally acquired during mineral exploration programs (Shives et al. 1997). This technique is cost-effective and rapid for geochemical mapping of the radioactive elements: potassium, uranium and thorium.

This section describes results from analysis of the radiometric data for the Rio das Velhas survey. Study of these data were un-

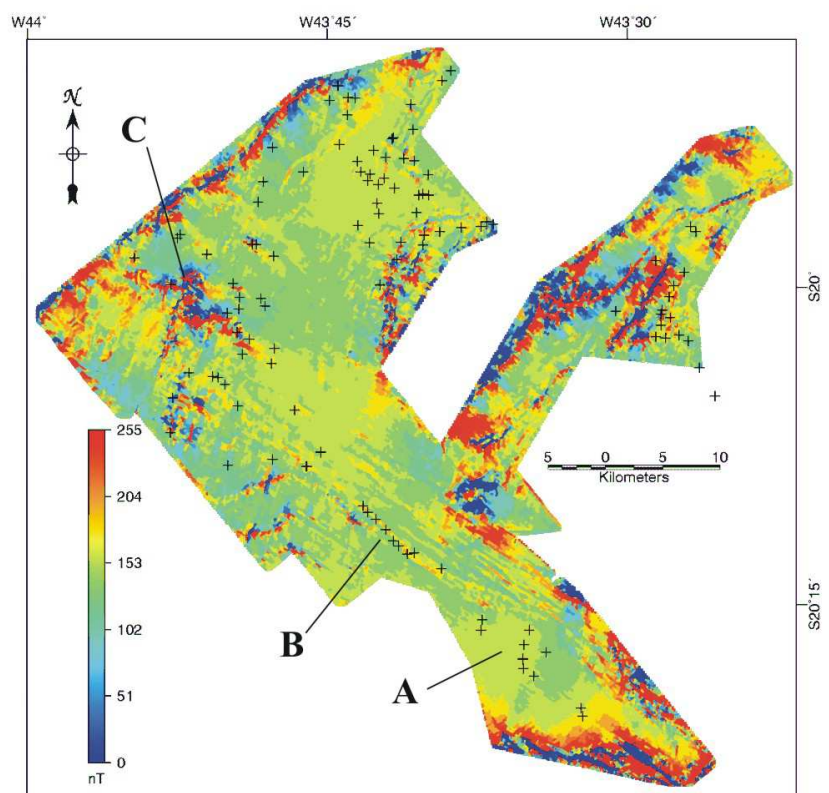

Figura 4 - Map showing the terrace of high pass. Histogram equalized, blue low and red high. Data are scaled from original values to a range between 1 to 255 . A-North-South structures and related occurrences; $B$-São Vicente Fault and related mines; $C$ - Morro Vermelho magnetization expression and mineralization sites.

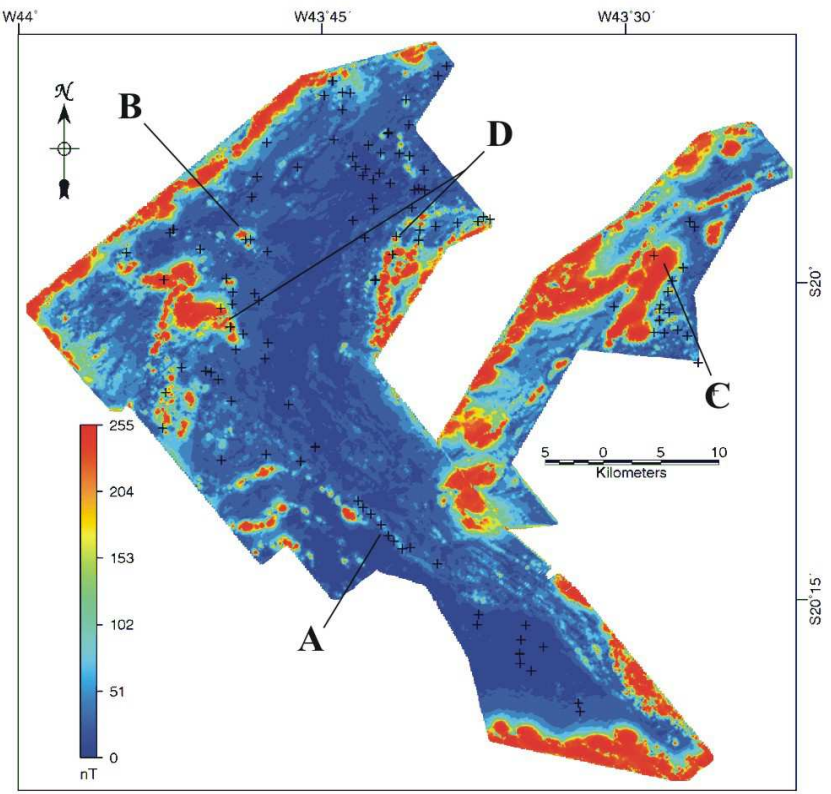

Figure 5 - Map showing the analytical signal amplitude with mine and occurrence locations. Histogram equalized, blue low, red high. In this map it is possible to associate the gradients of the analytic signal amplitude and the known gold mineralization. The mines that follows the trace of São Vicente System are associated with steep gradients (A); as well the anomaly that represents the Raposos (B), São Bento (C) and other mines associated with the Morro Velho Formation (D). 
dertaken with the goal to recognize and understand radiometric signatures associated with the host rocks important to mineralization. In the beginning, the aim was to use these data as an aid to lithological mapping by determining if a spatial correlation exists between the radiometric data and lithological rocks. However, there is an obvious strong relationship between the some mapped geologic units and the radiometric data. Personal discussions with various members of the geologic mapping team (Zuchetti, oral communication) revealed that the radiometric data, particularly the potassium data, were used heavily in guiding the mapping of particular geologic units. These units include Córrego do Sítio, Ribeirão Vermelho and Mindá Formations.

TOTAL COUNT (TC), POTASSIUM (K), THORIUM (eTh) and URANIUM (eU) CHANNELS The total count shows that are a good correlation between select units in the geological map, patterns and trends in the total count data. For example, units that have low radiometric response as the mafic and ultramafic rocks (Fig. 6a).

In the potassium image it is possible to select zones or units that have high concentrations of potassium (Fig. 6b). However, it is not possible, visually, to point to potassium haloes around mining deposits. The principal use of this map, at this scale, is in geological mapping. For gold exploration studies, another useful approach is to use these data in a statistical sense (Silva 1999, Silva et al. 1999). According to Hoover \& Pierce (1990), potassium haloes around mining deposits are well known from standard geochemical studies and potassium metassomatism can double the potassium concentration of potassium-rich rocks. These characteristics make the potassium the most useful pathfinder element (Dickson \& Scott 1997).

Anomalies in the thorium data map (Fig. 6c) the boundaries of the granitoids (for example: Bação Complex, Caeté Complex), the Paleoproterozoic metassediments of the Ouro Fino syncline (Figs. 1 and 2). At the base of this syncline is the Moeda Formation, a succession of Witwatersrand-type metaconglomerate, quartzite, and phyllite. Thorium is generally considered very immobile. However, some gold deposits show increases in $\mathrm{K}$ and Th, which suggest that Th was mobilized in hydrothermally altered systems. Ostrovskiy (1975) refers to a decrease in Th and an increase in K for the alteration environment in variety of ore deposits.

The uranium image shows good definition in mapping the granitoid rocks and the Ribeirão Vermelho Formation (Fig. 6d). The image shows short wavelength anomalies that correspond to noise caused by the variations in atmospheric radon concentrations during the course of the survey resulting in significant streaking in the image. This is a typical feature found in uranium images (Minty et al. 1997), in spite of the microleveling. Uranium is often enriched in gold deposits, however it is fairly mobile in an oxidizing environment (Hoover and Pierce 1990). Boyle (1979) suggests that pervasive hydrothermal alteration can remove uranium leaving negative aureoles.

COMPOSITE IMAGE AND RATIOS Potassium, uranium and thorium were assigned to the red, green and blue to create a composite RGB color model. The resulting image (Fig. 7 ) comprises colors generated from the relative intensities of the three components and represents subtle variations in the ratios of the three bands. Potassium was assigned to red, uranium to green and thorium to blue. Before combination, their individual histograms were contrast enhanced, using a histogram equalization to give the best color variation. Normally, the thorium is assigned to green and uranium to blue, because the blue tends to reduce the poorest signal-to-noise ratio of uranium channel (Millingan and Gunn 1997). However, for this work, the composite image presented showed a better result.

The composite image presents strong spatial correlations with the known geologic units. The mafic, ultramafics and the Paleoproterozoic banded iron formation appear darker than the surrounding units, indicating lower concentrations in $\mathrm{K}, \mathrm{U}$, and Th. The gneissic granites have a high total count radiometric response, appearing as white or blue (high thorium) in the ternary image. The highest radiometric response is illustrated by the dacitic rocks of the Ribeirão Vermelho Formation. The lithotypes with high potassium are in red and, in part, represent metasedimentary host rocks of the Nova Lima Group.

The ratio image tends to remove lithological differences and effects in the data caused by variations in the soil moisture, nonplanar source geometry, and errors associated with altitude correction. According to Darnley (1972), lithological differences tend to be removed because radioelement concentrations frequently vary as lithology change.

The eU/eTh and eU/K and ratios were useful for determining where relative concentrations of uranium are high. Some of the uranium anomalies are related to gold mines mapped in contact with and within the Quebra Osso Formation. If uranium is enriched in gold deposits and basic rocks shows little change in radioelement concentrations during the initial weathering, then the anomalies of the two ratios maps are directly correlated with the gold mineralization in this part of the area.

The eTh/K image shows some interesting features. The Thorium concentrations mark the trace of the Bem-te-vi fault, the Córrego dos Boiadeiros Formation, the contact between Morro Vermelho and Ouro Fino Formations, part of Mindá Formation in the Caeté Block (Fig. 2) and the banded iron formations, Algoma type, in the Santa Bárbara block. The highest thorium concentrations are in southern part of the area and are associated with metassediments of the São Bartolomeu block. There is not a large amount of information available regarding thorium mobility or distribution in gold deposits. It is difficult to say if part of the thorium-enriched area in the south was mobile or other not. However, there is a good geological correlation with the Complexo dos Boiadeiros Formation, structures and contacts suggesting that this radioelement was not mobile (Silva 1999).

The airborne frequency-domain eletromagnetics The application of HEM surveying has become broader. The method is traditionally used in prospecting for sulfide deposits, where the search for highly conductive to moderately conductive sulfides and moderately conductive shears zones for gold was and is an important task. The important advantage of this technique is the possibility to work in high or rugged terrains inaccessible to fixed-wing. High resolution HEM surveys have the capability to search for multiple conductors and small targets, such as the mapping of alteration zones.

In the Rio das Velhas Survey, the bird was flown 30 meters above the ground and data were collected every 5 meters along flight line at frequencies of 935, 4175 and $33000 \mathrm{~Hz}$. This wide range of frequencies provides good electrical resistivity mapping capability. The resistivity data may be displayed as maps or section. The low frequency $(935 \mathrm{~Hz})$ resistivity map identifies the electrical response from greater depth. In contrast, the high fre- 

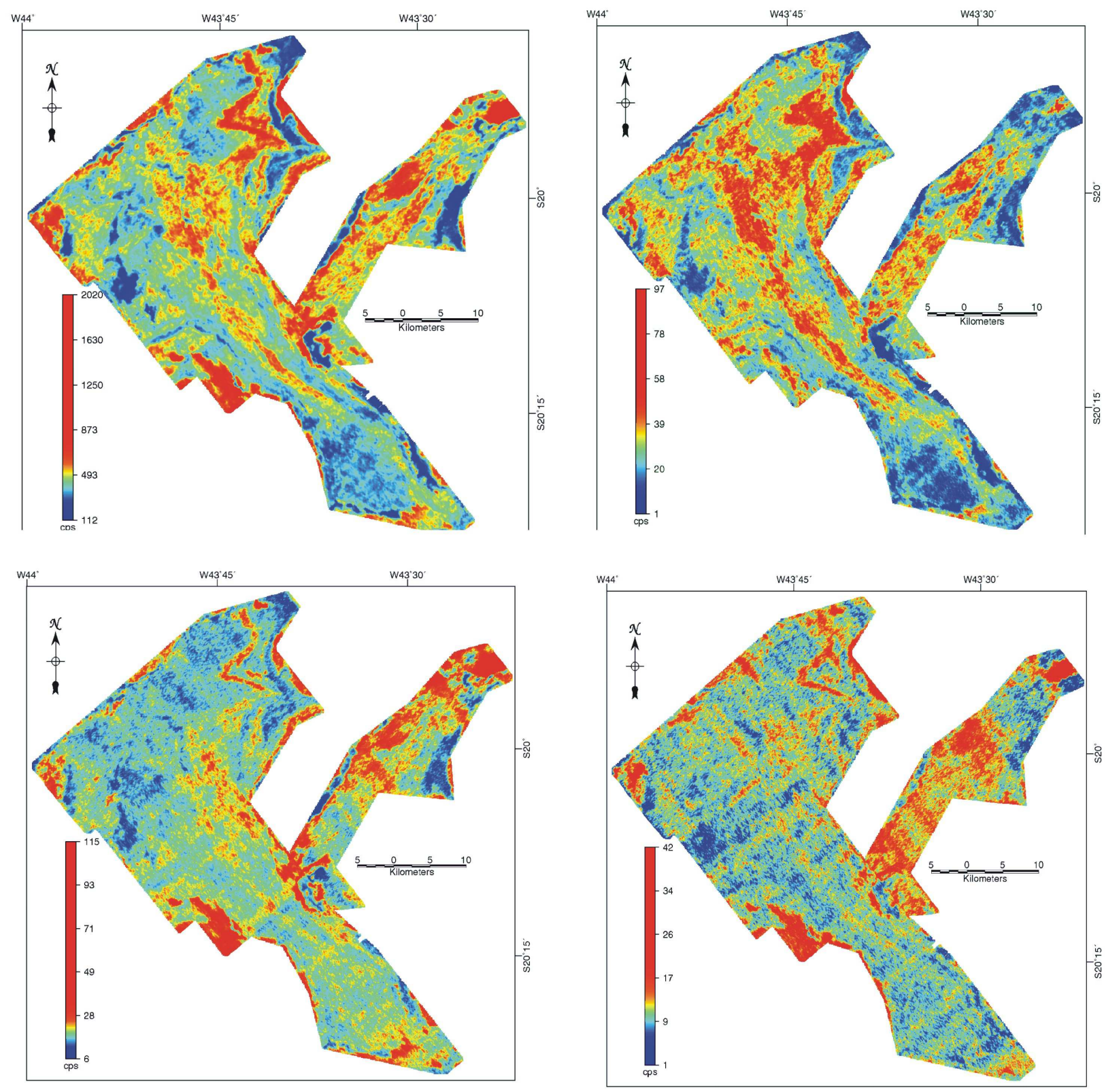

Figure 6- Gamaspectrometric images of the Rio das Velhas Project. a) Total Count; b) Potassium, c) Thorium and d) Uranium.

quency $(33,000 \mathrm{~Hz})$ resistivity map gives response towards the surface. The higher frequency $(33,000 \mathrm{~Hz})$ plays a supporting role by defining a near-surface, which can help in the recognition of the conductive zone at depth. The measured quantities, inphase and quadrature eletromagnetic response, can be displayed as apparent resistivity maps showing lateral changes, however, such maps provide no depth information.

According to Hildenbrand \& Perez da Gama (1993), the resistivity maps generated for the study area used the method proposed by Fraser (1978). The model is based on a half-space to obtain a parameter (such as apparent resistivity) which may be presented in sectional view or as contours on a plan map. The resistivity contour map will represent a full picture of the recorded EM information rather than discrete anomalies. The resistivity map can aid geologic mapping and the identification of difficult targets. Seve- ral profiles and maps might be prepared to the several frequencies used. The apparent resistivity parameters then can form the input to various interpretation schemes. Fraser (1978) called the generalized approach.

Resistivity images were prepared from the Rio das Velhas EM data set. Flight line data of $935 \mathrm{~Hz}, 4175 \mathrm{~Hz}$ and $33000 \mathrm{~Hz}$ frequencies were gridded to 50-meter cells, microleveled and converted to conductivity (1/resistivity). The conductivity ranges are small for the Rio das Velhas lithotypes, what is typical in Precambrian terrains (Palacky 1991). A logarithmic transformation was applied to the conductivity data in order to better distribute the range of values. This also allowed a better visual interpretation of the data and their relation to geologic sources. Typically, the middle and low frequency eletromagnetics are better channels to map multiple conductors and small targets at depth, because of some pro- 


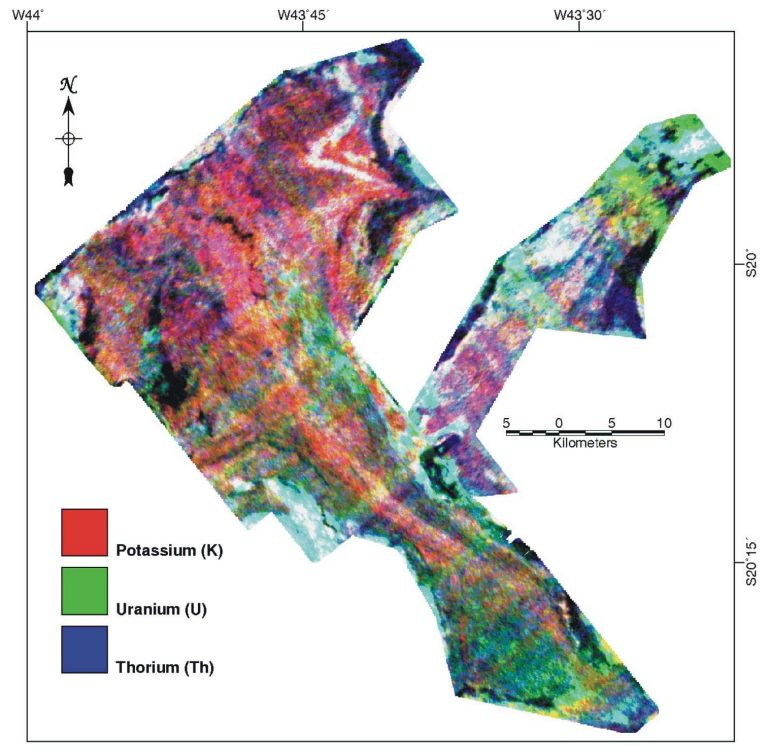

Figure 7 - Composite Image ( $R G B=K U T h)$ of the Rio das Velhas Greenstone Belt. The mafic and ultramafic, as well the banded iron formation (Algoma and Lake Superior type) are in black, the granitoids rocks in cyan, The Ribeirão Vermelho Formation in white and metassediments with high potassium has a magenta color.

blems associated with noise. In weathered terrains, such as this study, the middle channel seems to provide the image with the least amount of noise (Fig. 8a).

In assessing a method theoretical capability, the maximum depth of investigation as well as resolution of parameters is a concern. Depth of investigation is difficult to quantify because it depends on many factors (Spies \& Frischknecht 1991). Earth materials usually have a conductivity $\sigma>10^{-4} \mathrm{~S}\left(\rho<10^{4} \Omega . \mathrm{m}\right)$ (Zonge \& Hughes 1991). One approach for estimating the practical depth of investigation is based on a plane wave that can be derived from asymptotic relations based on a uniformly layered half space (Bostick 1977):

$$
\mathrm{D}=(356 \sqrt{ } \rho / f) \text { in meters }
$$

where: $\mathrm{D}=$ depth of penetration, $f=$ frequency and $\rho=$ resistivity

The penetration is dependent upon two parameters: the resistivity of the earth and the frequency of the signal being used. Penetration is shallower with decreasing resistivities and increasing frequencies. In the other hand, penetration is deeper with increasing resistivities and decreasing frequencies (Zonge \& Hughes 1991). According to a resistivity measurement assay carried out in the area by Palacky \& Kadekaru (1979), the lowest value pointed out for the schists of Nova Lima Group is around $80 \Omega$. This value was used for the calculation of the estimated depth as shown below. The values are probably the lowest ones for the estimated depth (Table 1).

The results above estimates a depth of investigation for the HEM data of the Rio das Velhas airborne survey and give us an idea of how deep is seeing with this particular method. The $4175 \mathrm{~Hz}-$ eletromagnetics was the considered the best channel in this data and targets studied seem to be around $50 \mathrm{~m}$ deeper.
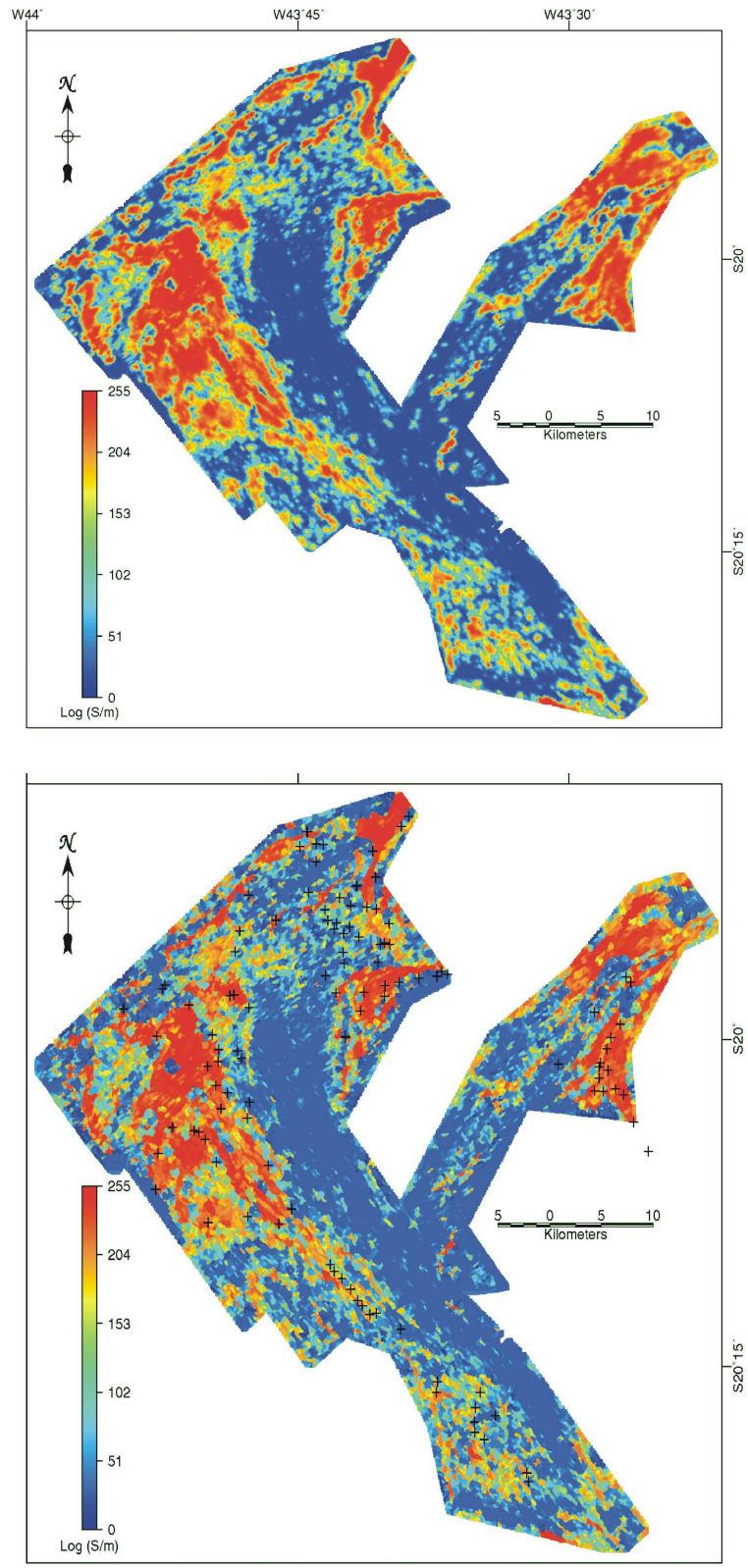

Figure 8-a) Conductivity image for the $4175 \mathrm{~Hz}$-eletromagnetics of the Rio das Velhas Greenstone Belt Survey. B)Terrace of the $4175 \mathrm{~Hz}$-eletromagnetics of the Rio das Velhas Greenstone Belt Survey with mine locations. Data are scaled from original values to a range from 1 a 125. Map emphasizes boundaries between rocks with varying conductivities.

Grids of the 935, 4175 and $33000 \mathrm{~Hz}$ resistivities converted to conductivities were terraced to produce inferred conductivity maps. These maps emphasize abrupt boundaries between rocks with different conductivities. Figure $8 \mathrm{~b}$ presents the terrace conductivity map from $4175 \mathrm{~Hz}$ resistivity data. Data are scaled from log values to a range of 1 to 255 . Map emphasizes boundaries between different rocks with varying conductivities. The most important host rocks or mineralized domains show high conductivity response. There is a strong correlation of these domains with 
the mapped Morro Vermelho, Quebra Osso and Ouro Fino Formations (Fig. 2). Such domains host the known gold mineralization, illustrating the utility of this layer to improve the geologic map and the understanding of mineralization.

The 935, 4175 and 33000 conductivities $(\log \mathrm{S} / \mathrm{m})$ were assigned to the red, green and blue of a RGB color model. The result image (Fig. 9) comprises colors generated from the relative intensities of the three components and represents subtle variations in the ratios of the three bands. $4175 \log \mathrm{S} / \mathrm{m}$-conductivity was assigned to red, 33,000 $\log \mathrm{S} / \mathrm{m}$-conductivity to green and $935 \log \mathrm{S} / \mathrm{m}$ conductivity to blue. Before combination, their individual histograms were contrast enhanced, using a histogram equalization transformation to give the best color variation.

Airborne eletromagnetic systems were developed to detect orebodies in a resistive host but have been a little used for geological mapping (Green 1998). However, this is a not a straightforward process, because eletromagnetic data differ from magnetics and radiometrics in two important ways. Firstly the system is more complex and secondly it generates multichannel data of high dimensionality. According to Green (1998), dimensionality "is the number of linearly independent pieces of information acquired at each station along line".

The higher dimensionality of airborne eletromagnetic data means that the simple display strategies used for magnetics and radiometrics are inadequate to display the full information content of the data. Magnetic is a single channel measurement that is adequately displayed by pseudocolor or greyscale images, whilst radiometrics are essentially three-dimensional data can be displayed as RGB color composite images. (Green 1998).

The RGB composite image (Fig. 9) was useful to delineate the high conductivity response in white. This image plays a supporting role by illustrating the conductivity bodies in different depths. It means that conductivity features vary from near-surface until around 100 meters, and also shows the coherence of the data. Representing the three frequencies as a composite image is an interesting way to look at the data and to get information about the depth, shape of conductivity units, and to interpret them in terms of geology.

\section{GEOLOGICALANDGEOPHYSICALINTERPRETATIONAND} THEIRRELATIONTOSTRUCTURAL, LITHOLOGICALAND MINERALIZATION SETTING Analysis of geophysical features provides new insights into structural framework and can help geologists target new areas for mineral exploration. Recognizable patterns of geophysical anomalies correspond to geological targets for mineral potential, such as Archean banded iron formations and associated metavolcanoclastic rocks. The interpretation of high-resolution magnetics has provided both an overview of the regional structure as well as further insight into structural controls of the Archean-greenstone-hosted-gold deposits. Interpretations of the aeromagnetic maps show one detailed assessment of the known and north-south structures in the area. The recognition of the extension of north-south structures has important implications for the understanding of Rio das Velhas Tectono-thermal event.

North-south structures located in the southern portion of the area are evident as north-south trending gradients in the reducedto-pole magnetic anomaly map and associated derivative products (Figs. 4, 5 and 6). These structures were previously mapped with geologic mapping (Golia et. al. 1995, Endo et. al. 1996, Endo 1997) and were ground truthed with geologic fieldwork. The rocks of
Table 1 - Estimation of depth of investigation for the HEM data of Rio das Velhas Airborne Survey.

$\begin{array}{ll}\text { FREQUENCY }(\mathrm{Hz}) & \text { DEPTH(m) } \\ 935 & 100 \\ 4175 & 50 \\ 33,000 & 20\end{array}$

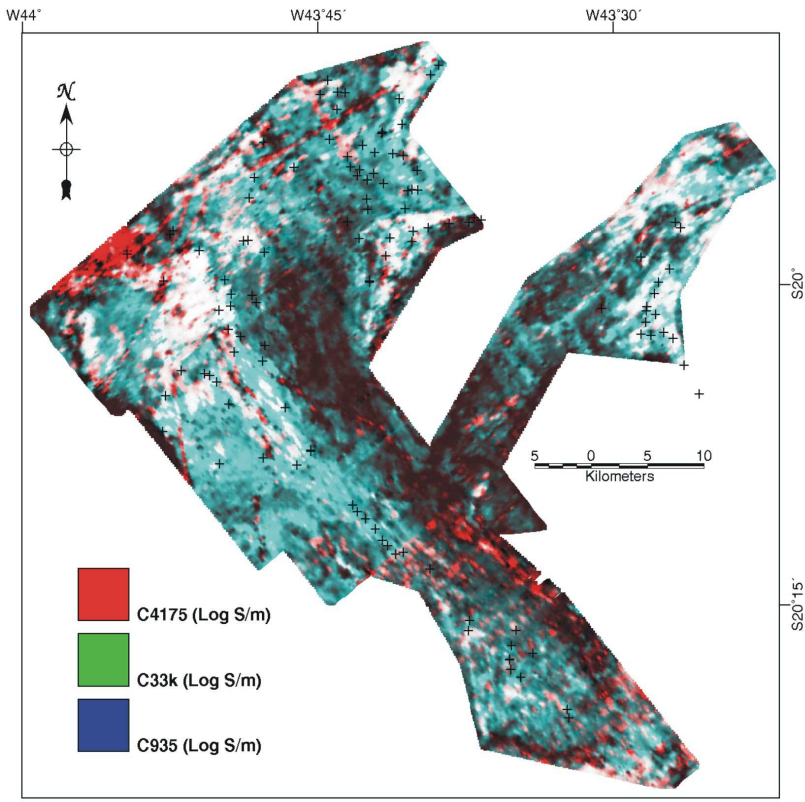

Figure 9-Composite image (RGB) of the 935, 4175 and 33000 conductivity images of the Rio das Velhas Greenstone Belt with mining locations.

Nova Lima Group, in this area, have a mylonitic foliation that is subvertical and strikes north south with a horizontal mineral lineation (Endo 1997, Silva 1999).

According to Endo (1997), kinematic indicators suggest superposed successive dextral and sinistral components. Endo \& Carneiro (1996) and Endo (1997) presented studies on the complex and the supracrustal rocks, and they suggested a transpressional tectonic regime of Neoarchean age for the Quadrilátero Ferrífero. According to Endo \& Carneiro (1996), the coincidence of the NS structural orientations in the metamorphic complexes and in the supracrustal rocks of the Rio das Velhas Supergroup show that these segments were targets of successive tectonic reactivations in crustal weakness zones of ductile to brittle nature generated during the Mesoarchean.

There are two large Paleoproterozoic structures that can be mapped with the aeromagnetic data: the Bem-te-vi and São Vicente faults (Endo 1997). The Bem-te-vi fault separates different magnetic domains in the Greenstone Belt. The São Vicente system is one of the most important gold structural controls. It also marks the contact between the Nova Lima and Maquiné Groups.

There are a group of mines and prospects that plot in the trace of the São Vicente fault. This area is easily identified in the upward continuation data, in which the São Vicente fault presents itself as 
a longer wavelength anomaly implying a deep-seated structure. Moreover, the area is also marked by a huge quartz vein, concordant with the mine locations, indicating the region of higher fluid pressure and accumulation. The feature of this zone changes in other derivative products and it is possible to define this fault segment and the mining association.

Another important group of structural elements is represented by the Paleoproterozoic NE structures. They are predominant and cut the other structures mentioned. In the field, they represent a broad system of fractures and lineaments. The borders of the survey is in contact with the Minas Supergroup and the high frequency associated with these tectonic contacts are due to BIF of Lake Superior type, that occur in these zones.

The four radiometric maps (total count, potassium, uranium and thorium) were individually enhanced by manipulation of their histograms and then displayed in pseudo-color. These data were imaged as ternary displays (R: $\mathrm{B}: \mathrm{G}=\mathrm{K}: \mathrm{U}$ : Th). Individual lithological units can be traced due to their distinctive radiometric response. The mafic, ultramafics and the Paleoproterozoic units appear darker than the surrounding units, indicating lower concentrations in all three radiometric elements. The gneissic granites have a high total count radiometric response, appearing as white or blue (high uranium) in the ternary image (Fig. 7). Of particular importance is the identification of dacitic rocks in white that were mapped as the Ribeirão Vermelho Formation by geologists of the Rio das Velhas' team. This formation consists of piroclastic dacitic tuffs and agglomerate horizons with minor lava intercalation (Pinto \& Silva 1996).

The radiometric data are an excellent tool for mapping and tracing individual lithological units in areas of outcrop. The mafics, ultramafics and Paleoproterozoic units are distinctive in potassium, total count and RBG maps, because of their low radiometric signature (Fig. 7). The gneissic granites and dacitic rocks have a high total count radiometric response, appearing as white or blue (high uranium) in the ternary image (Fig. 7).

Hoover \& Pierce (1990) showed that aerial gamma-ray survey- ing signatures of Au deposits were variable with $\mathrm{K}$ being the most reliable pathfinder. Even where $\mathrm{Au}$ is within quartz veins, hydrotermal alteration of host rocks can give detectable haloes. This assumption seems valid to the Rio das Velhas Greenstone Belt case, where potassium is associated with many of the favorable host rocks. Although there is not a particular radiometric signature for gold deposits, studies summarized by Hoover \& Pierce (1990) show that changes in the all three radioelements can occur and may be detected in aerial gamma-ray surveys.

The most important host rocks or mineralized domains show high conductivity response. There is a strong correlation of these domains with the mapped Morro Vermelho, Quebra Osso and Ouro Fino Formations. Such domains host the known gold mineralization, illustrating the utility of the EM data to improve the geologic map. The best point to check is the conductivity signature in the Santa Bárbara block. The signature with the mine points regards to Quebra Osso Formation. The other covers part of the mapped Córrego do Sítio Formation that showed in the same block to have low conductivity response. These assumption suggest that efforts can be made to check these information and, may be, point out extension of host rocks in the area of the Rio das Velhas Greenstone Belt.

The 935, 4175 and 33000 conductivities $(\log \mathrm{S} / \mathrm{m})$ were assigned to the red, green and blue of a RGB color model (Fig. 9). The mafic, ultramafics and the metavolcanoclastic rocks appear in white indicating a high conductivity response. Cyan indicates a medium conductivity response, whilst the resistivity areas appear darker with some red spots. The Rio das Velhas mining distributions plot inside of white and blue areas, except for some occurrences.

Acknowledgments We thank the CNPq for concession of the research project (Processo 420117/01-0) that supported part of this research. To Jeffrey Phillips (USGS), Tracy Sole Van De Hoop (USGS), Misac Nabighian (Colorado School of Mines) and Júlio Lyrio (PETROBRAS) for their help during the course of this work. To the RBG referees for suggestions to the manuscript.

\section{References}

Bostik F.X.Jr. 1977. A simple almost exact method of MT analysis. In: Proceedings of the University of Utah workshop on Electrical Methods in Geothermal Exploration, p.175-188.

Boyle R.W. 1979. The geochemistry of gold and its deposits. Geological Survey of Canada Bulletin 280, 584p.

Brigs I. C. 1974. Machine coutouring using minimum curvature. Geophysics, 39 (1), 39-48.

Chemale Jr. F., Rosière C.A. \& Endo I. 1991. Evolução tectônica do Quadrilátero Ferrífero, Minas Gerais - Um modelo (Tectonic Evolution of the Quadrilátero Ferrífero, Minas Gerais. A Model). Pesquisas, 18: 104-127.

Chemale Jr. F., Rosière C.A. \& Endo I. 1994. Tectonic Evolution of the Quadrilátero Ferrífero, MG, Brazil. Precambrian Research, 65:2554.

Clark D.A. 1997. Magnetic petrophysics and magnetic petrology: aids to geological interpretation of magnetic surveys. ASGO Journal of Australian Geology \& Geophysics, 17(2):83-103.

Cordani U.G., Kawashita K., Mueller G., Quade H., Reimer V., Roeser H.P. 1980. Interpretação tectônica e petrológica de dados geocronológicos do embasamento do bordo sudeste do Quadrilátero Ferrífero, Minas Gerais. Acad. Bras. Cienc., Anais...Rio de Janeiro, 52:785-799.

Cordell L. \& McCafferty A.E. 1989. A terracing operator for physical property mapping with potential field data. Geophysics, 54 (5): 621-634.

Darnely A.G. 1972. Airborne gamma-ray survey techniques. In: Uranium prospecting handbook. S.H. Bowie M. Davis and D. Ostle, eds., London, The Institute of Mining and Metallurgy, p.174-211.

Dickson B.L. \& Scott K.M. 1997. Interpretation of aerial gamma-ray surveys - adding the geochemical factors. ASGO J. Austral. Geol. Geophysics, 17:187-200.

Dorr II J.V.N., Gair J.E., Pomerene J.G., Rynearson G.A. 1957. Revisão da estratigrafia pré-cambriana do Quadrilátero Ferrífero. Departamento Nacional da Produção Mineral - Divisão de Fomento da Produção Mineral, 81: 1-31 (avulso).

DORR II J.V.N. 1969. Physiografic, stratigraphic, and structural development of the Quadrilátero Ferrífero, Minas Gerais. U.S.G.S. Paper, 641-A:1-110. 
Endo I. \& Carneiro M.A. 1996. O regime tectônico Neoarqueano no Quadrilátero Ferrífero: um modelo transpressional. In: Congr. Bras. de Geologia, 39, Salvador. Anais ..., SBG, 1: 414-416.

Endo I. 1997. Regimes Tectônicos do Arqueano e Proterozóico no Interior da Placa Sanfranciscana: Quadrilátero Ferrífero e Áreas Adjacentes, Minas Gerais. Instituto de Geociências, Universidade de São Paulo, São Paulo. Tese de Doutoramento, 242p.

Ladeira E.A. 1980. Metallogenesis of Gold at the Morro Velho Mine, Nova Lima District, Quadrilátero Ferrifero, Minas Gerais, Brazil. London. 272p. Ph.D. thesis, University of Western Ontario, 272p.

Fraser D.C. 1978. Resistivity Mapping With an Airborne Multicoil Electromagnetic System. Geophysics, 43(1):144-172.

Gair J.E. 1962. Geology and ore deposits of the Nova Lima and Rio Acima quadrangles, Minas Gerais, Brazil. U.S.G.S. Professional Paper, Washington, 341-A:1-87.

Golia A., Cunha E.M. DA, Oliveira C.G., Ferreira G.S. 1995. Geologia do Greenstone Belt Rio das Velhas no Distrito Aurífero de São Bartolomeu, M.G. In: $8^{\circ}$ SIMPÓSIO DE GEOLOGIA DE MINAS GERAIS, 13, Salvador. Anais ..., SBG, p. 67-69.

Grauch V.J.S. \& Millegan P.S. 1998. Mapping intrabasinal faults from high-resolution aeromagnetic data. The Leading Edge, 53-55.

Green A. 1998. The use of multivariate statistical techniques for the analysis and display of AEM data. In: Proceedings ..., Airborne Eletromagnetics (AEM98), edited by b. Spies D., Fitterman S., Hollady G., Liu. Exploration Geophysics, 29:77-82.

Gunn P.J., Minty B.R.S., Milligan P.R. 1997. The Airborne GammaRay Spectrometric Response Over Arid Australian Terranes. In: Exploration 97: Fourth Decennial International Conference on Mineral Exploration, Proceedings ..., edited by A.G. Gubins, 1997, 733-740.

Hildenbrand J.D. \& Perez da Gama M.F. 1993. Levantamento aeromagnetométrico, gamaespectrométrico e eletromagnético. Projeto Rio das Velhas. Relatório Final, V1, texto técnico, Prospec S/A, 47 p.

Hoover D.B. \& Pierce H.A. 1990. Annotated Bibliography of GammaRay Methods Applied to Gold Exploration. U.S.G.S. Open-File Report, 90-203, 23p.

Meyers J.B., Worrall L., Lane R. \& Bell B. 2001. Exploring through cover - the integrated interpretation of high resolution aeromagnetic, airborne electromagnetic and ground gravity data from the Grant's Patch area, Eastern Goldfields Province, Archaean Yilgarn Craton. Part C: Combining geophysical methods for a holistic exploration model. Exploration Geophysics, 32:198-202.

Millingan P.R. \& Gunn P.J. 1997. Enhancements and presentation of airborne geophysical data. ASGO Journal of Australian Geology and Geophysics, 17 (2):31-38.

Minty B.R.S., Luyendyk A.P.G., Brodie R.C. 1997. Calibration and data processing for airborne geophysical data. ASGO Journal of Australian Geology \& Geophysics, 17(2):51-62.

Nabighian M.N. 1972. The analytical signal of two-dimensional magnetic bodies with polygonal cross-section: its properties and use for automated anomaly interpretation. Geophysics, 37(3):507-517.

Oliveira G.A.E., Clemente P.L.C., Vial D.S. 1983. Excursão à Mina de Morro Velho. In: Simp. de Geol. de Minas Gerais, 2, Belo Horizonte, 1983. Anais ..., Belo Horizonte, SBG, Boletim, 3:497-505.

Oliveira O.A.B. 1986. As falhas de empurrão e suas implicações na estratigrafia e metalogênese do Quadrilátero Ferrífero, MG. In: Congr. Bras. De Geologia, 34, Goiânia, Anais ...... SBG, 2:10741087.

O'Rourke J.E. 1957. The stratigraphy metamorphic rocks of the Rio das Pedras and Gandarela Quadrangles, Minas Gerais, Brazil.
University of Wisconsin, EUA. PhD Thesis, 106p.

Ostrovskiy E.A. 1975. Antagonism of radioactive elements in wallrock alteration fields and its use in aerogamma spectrometric prospecting. International Geology Review, 17(4):461-468.

Palacky G.J 1991. Resistivity characteristics of geologic targets. In: Electromagnetic Methods in Applied Geophysics. Edited by M.N. Nabighian Society of Exploration Geophysicists, Tulsa, Oklahoma, V1, 53-129.

Palacky G.J. \& Kadekaru K. 1979. Effect of tropical weathering on electrical and electromagnetic measurements. Geophysics, 44(1):2138.

Parasnis D.S. 1986. Principles of Applied Geophysics, $4^{\text {th }}$ ed., Chapman and Hall, London, 1986.

Philipps J. D.1997. Potential-Field Geophysical Software for the PC, version 2.2. U.S.G.S. Open-File Report 97-725, 34 p.

Pinto P.C. \& Silva L.C. 1996. Contrasting Tectono-Stratigraphic Domains in The Rio das Velhas Greenstone Belt (RVGB), MG, Brazil. In: Symposium Archaean Terranes of the South American Platform. Brasília, SBG, 1996. Anais ..., 23-25.

Pinto P.C. 1996. Introdução. Projeto Rio das Velhas. Mapa Geológico Integrado. Escala: 1:100.000. Texto Explicativo. Programa de Estudos Mineiros. Convênio DNPM-CPRM. DNPM-Secretaria de Minas e Energia-Ministério de Minas e Energia. Belo Horizonte, 1996, 1-10.

Ribeiro-Rodrigues L.C. 1998. Gold Mineralization In Archaean Banded Iron Formation, Quadrilátero Ferrifero, Minas Gerais, Brazil The Cuiabá Mine. Rwth Aachen, Germany, Aachener Geowinssenschftiche, Tese de Doutoramento, 262p.

Roest W.R. \& Pilkington M. 1993. Identifying remanent magnetization effects in magnetic data. Geophysics, 58:653-659.

Roest W.R., Verhoef J., Pilkington M. 1992. Magnetic interpretation using 3-D analytic signal. Gephysics, 57(1):116-125.

Shives r.b.k., Charbonneau B.W., Ford K.L. 1997. The Detection of Potassic Alteration by Gamma-Ray Spectrometry - Recognition of alteration Realted to Mineralization. In: Exploration 97: Fourth Decennial International Conference on Mineral Exploration, Proceedings ..., edited by A.G. Gubins, 1997, p.741-752.

Schorscher H.D. 1978. Komatiitos na estrutura greenstone belt Série Rio das Velhas. Quadrilátero Ferrífero, Minas Gerais, Brasil. In: CONGRESSO BRASILEIRO DE GEOLOGIA, 30, Recife. Anais ......, Boletim Especial, 1:292-293.

Silva A.M. 1999. Integração de dados geológicos e geofisicos utilizando-se uma nova técnica estatística para seleção de alvos para exploração mineral, aplicada ao Greenstone Belt Rio das Velhas, Quadrilátero Ferrífero. Instituto de Geociências, Universidade de Brasília, Brasília, Tese de Doutoramento, 195p.

Silva A.M., McCafferty A.E. \& Pires A.C.B. -1999 - A new approach to map host rock for gold exploration in the Rio Das Velhas Greenstone Belt, Quadrilátero Ferrífero, Minas Gerais, Brazil. Proceedings of The $6^{\text {th }}$ International Congress of the Brazilian Geophysical Society, 1999, CD.

Spies B.R. \& Frischknecht F.C. 1991. Electromagnetic Sounding. In: Electromagnetic Methods in Applied Geophysics. Edited by M.N. Nabighian Society of Exploration Geophysicists, Tulsa, Oklahoma, V2, 285-426.

Sweeney R.E. 1990. IGRFGRID - A program for creation of a total magnetic field (International Geomagnetic Reference Field) grid representing the earth's main magnetic field: U.S.G.S. Open-File Report 90-45a, $37 \mathrm{p}$.

Vieira F.W.R. \& Oliveira G.A. 1988. Geologia do Distrito Aurífero de Nova Lima, Minas Gerais. In: Schobbenhaus C. \& Coelho. C.E.S. 
(coord). Principais Depósitos Minerais do Brasil. Brasília, DNPM/ CVRV, V(3): 377-391.

Webring M.W. 1981. MINC - A gridding program based on Minimum Curvature: U.S.G.S. Open-File report 81-1224, 11p.

Zonge K.L. \& Hughes L.J. Controlled Source Audio-Frequency Magnetotellurics. In: Electromagnetic Methods in Applied Geophysics. Edited by M.N. Nabighian Society of Exploration Geophysicists, Tulsa, Oklahoma, V2:713-810.

Zucchetti M., BaltazarO.F., Raposo F.O. 1996. Estratigrafia. Projeto
Rio das Velhas. Mapa Geológico Integrado. Escala: 1:100000. Texto Explicativo. Programa de Estudos Mineiros. Convênio DNPMCPRM. DNPM-Secretaria de Minas e Energia-Ministério de Minas e Energia. Belo Horizonte, 1996, 13-42.

Manuscrito SSR-03

Recebido em 29 de agosto de 2002

Revisão dos autores em 25 de março de 2003

Revisão aceita em 20 de abril de 2003 